\title{
THE PROBLEMS OF CONSERVATION OF CORAL REEFS \\ IN NORTHWEST SABAH
}

\author{
by \\ Nigel P.E. LANGHAM ${ }^{1)}$ and JACK A. MATHIAS ${ }^{2)}$
}

\begin{abstract}
In March 1974 a survey was made of the coral reefs of NW Sabah centered on three main areas (1) Kota Kinabalu, (2) Kudat and (3) Labuan. At various sites within these areas, the coral reefs were assessed according to the extent of living coral, the damage resulting from fish blasting, mining and sedimentation, and the accessibility for tourism.

The coral reefs in this region support a significant fishery accounting for about 30 percent of the fish landings both in weight and monetary value. Reef fish are caught by lines, gill nets, and illegal use of explosives. The latter method has seriously damaged a number of reef habitats resulting in a marked drop in the fauna including valuable fish and invertebrates.

Coral mining for limestone used for foundations of buildings and roads has been carried out on accessible reefs near Labuan and Kota Kinabalu. The removal of coral heads has resulted in extensive reef damage especially near Labuan.

Recent efforts have been made to preserve these reefs and has led to the establishment of a national park around Pulau.Gaya. However, a number of other areas require protection both to safeguard the fishery and promote tourism.
\end{abstract}

\section{INTRODUCTION}

In March 1974, a team of scientists from Universiti Sains Malaysia visited Northwest Sabah with the object of defining coastal marine resources of the region and assessing environmental vulnerability of those resources to oil spills. Recently, offshore drilling has begun and seepage or spillage from drilling or transport operations may threaten various marine ecosystems and the livelihood of local people dependent upon them. One part of this survey involved an inspection of the coral reefs in three main areas: Kota Kinabalu, Kudat Peninsula, and Labuan. This survey reported the general condition of the reefs in these areas. (MATHIAS \& LANGHAM 1975).

\section{THE REEF FISHERY AND FISH BLASTING}

The coral reef ecosystems in this region (Fig. 1) contains a number of important fish species e.g. snappers and fusiliers (Lutjanidae), pigfaced bream (Lethrinidae), wrasses (Labridae), parrot fishes (Scaridae), rabbit fishes (Siganidae), groupers (Serranidae), and grunters (Pomadasyidae).

1) School of Biological Sciences, University Sains Malaysia, Penang, Malaysia.

2) Zoology Department, University of British Columbia, Vancouver, BC, Canada V6T 1W5. 
The reef fishery constitutes one of the most important fisheries on the west coast of Sabah, accounting for 2900 tons or about 30 percent

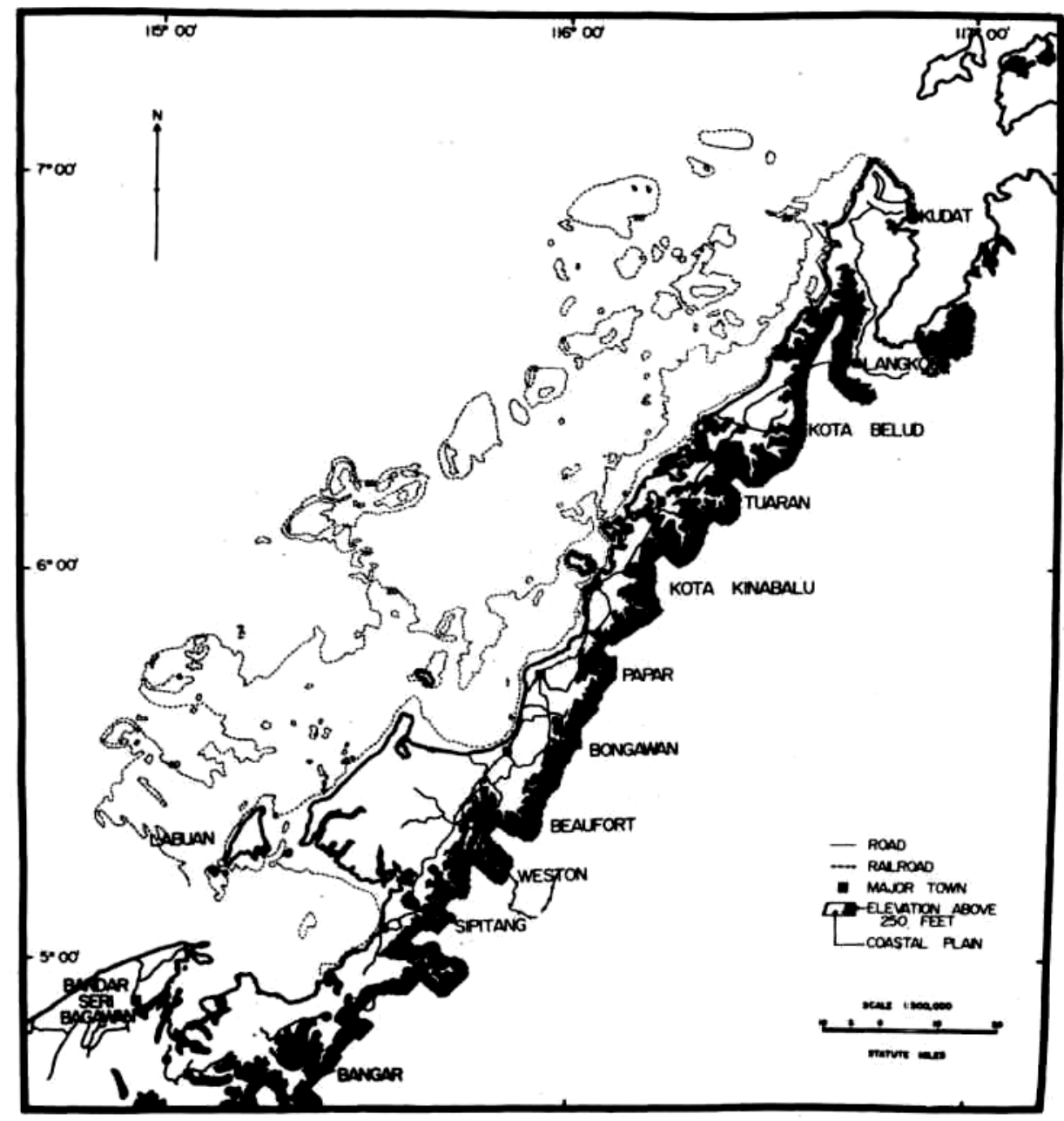

Figure 1. Map of Northwest Sabah.

of the total fish landed, with a market value of about M\$ 3V4 million (about US\$ $1 \frac{1}{4} \mathrm{~m}$ ) or 30 percent of the total earnings from fish. Reef fish are particularly important in the Kota Kinabalu area, but are secondary to the combined landings of mackerel (Scombridae) and pomfret (Stromateidae) at Labuan (Fig. 2). The total combined landings of mackerel and pomfret is about 3100 tons. (Fisheries Department, Sabah, 1974 Annual Report). 


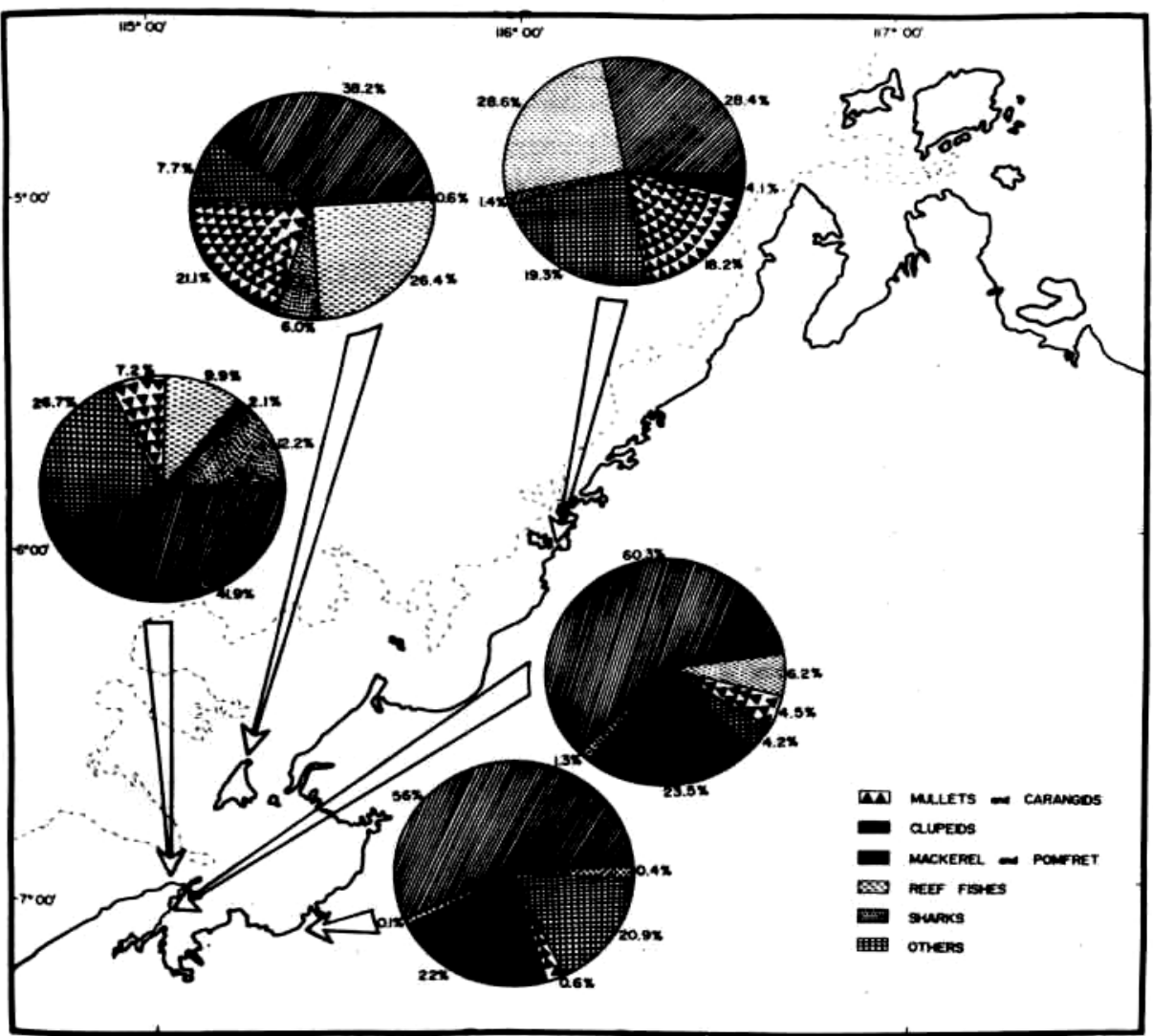

Figure 2. Map of Northwest Sabah showing the percentage composition of market landings of major groups of fish (after CHUA \& MATHIAS 1975)

The coral reefs are not only important habitats for many commercial fish species, but also contain a variety of invertebrates, many of which are valuable sources of protein. For example, at least six species of spiny lobsters (Panulirus spp.) occur on the coral reefs of Northwest Sabah. Usually they are caught by speargun or grapple and although of relatively little commercial importance, they represent a considerable potential which the Sabah Fishery Department is currently exploring. Also, various molluscs such as the giant clam, Tridacna, spider shells, Lambis; top shells, Trochus; cowries, Cypraeidae and others - Murex, Tonna, Strombus, and Cassis are found on the reef and are taken by local collectors. 
Most of the reef fish landed are caught by hand-lines or floating gillnets. However, it is apparent that carbide bombs are widely used. In these instances, fish are attracted to the area by bait and the bomb devised so that it explodes on reaching the reef surface. Although the use of explosives is illegal, this method of fishing is still widely practiced. For example, out of a total of 55 species recorded at a "tamu"* near Penumpang, 39 species were obtained by the use of explosives (CHUA \& MATHIAs 1975). Fish caught by such means can be detected by the severe and extensive internal haemorrhaging, and in some cases fractured vertebral columns. Such methods are particularly used to catch shoaling fish such as fusiliers and carangids.

It would appear that many fish caught by unlicensed fishermen are taken by this means and are not shown on Fishery Department landing figures. Not only is this method unselective, killing fish of all size and life stages, both desirable and undesirable species, but it also produces craters of one to three metres diameter in the reef, knocking down table top and staghorn Acropora and similar branching corals.

The blasting can severely damage the reef resulting in the alteration or destruction of the reef community. When the habitat is altered in this manner, most of fish and many invertebrates disappear, and are replaced by a community dominated by corals of the genus Fungia, sea urchins of the genus Diadema and numerous species of Sea cumbers. In some cases, the coral rubble becomes covered with algae (Cladophora spp.) which prevents the establishment of coral larvae (Planula), this inhibiting coral recolonisation. A similar phenomenon of algal succession following the death of corals by sewerage, silt and freshwater has been well documented in Hawaii (WoOD \& JOHANNES 1975)

\section{CORAL MINING}

In Sabah, especially in the Labuan and Kota Kinabalu areas, the coral skeleton provides a relatively easy accessible source of limestone $\left(\mathrm{CaCO}_{3}\right)$ for road building and land reclamation. Some of this coral is collected by small boats over shallow reefs, but the majority is collected by larger boats fitted with power winches. These boats search for large coral heads generally of the genera Goniopora or Porites. Divers fix cables to the base of the coral head which is then broken off and hauled into the boat. This process frequently involves dragging the coral heads over the reef until they can be hauled vertically into the boat and it is this dragging that causes extensive damage to the reef. As with fish blasting, associated with this destruction is the impoverishment of the area with the disappearance of most of the fish and associated

*) Local fair where villagers sell locally obtained produce. 
invertebrates. LuLOFS (1973) has estimated that on average, a single coral head extraction destroys an area of 10 feet wide and 25 feet long. Limestone contractors at Kota Kinabalu estimated that 450 tons were extracted on a good day. The average weight of a coral head is four tons, this represents about 110 coral heads per day per boat. A full boat carries about 64 four-ton heads; so that 110 heads represents more than one trip per day.

In 1965, one contractor operated two boats, each of which brought two loads per day which represents 320 cu.yd. of limestone, but accessible heads became scarcer so that by 1969 extraction was reduced to one trip per day or $160 \mathrm{cu}$. yds. per day. In 1974, 100-120 cu.yd. per day was a representative extraction figure because of the increased distances involved and the boats not being able to operate in rough weather which were more likely offshore. It is estimated that in recent years about 20,000 cu.yd. of coral was mined per year (110 cu.yd. per day x 22 days per month x 8.5 months per year), valued at M\$170,000 (M\$8.00 per cu.yd.) or US\$65,000 (US\$3.20 per cu.yd.). Only 36 persons are employed in this extraction of coral which is insignificant compared with the persons this possible fishery that these reefs could have sustained.

If 100 coral heads are mined each day and each head extracted damages an area of 250 sq.ft. (23 sq.m.per day) this would represent the destruction of $4.7 \times 10^{6}$ sq.ft. per year (43.7 ha. per year). If an average reef slope is approximately $200 \mathrm{ft}$. wide, then the annual mining would be equivalent to the destruction of about 4.2 miles $(6.8 \mathrm{~km})$ of reef front. Although this is a rough approximation, it gives some idea of the destruction possible.

\section{THE EXTENT OF MINING}

Reef destruction by mining is most extensive around Labuan where it has now extended to neighbouring islands. Near Kota Kinabalu, two platform reefs off Pulau Gaya were examined by LULOFs in 1973, but nine months later these were found to be extensively damaged by both blasting and mining (LuLOFS 1973; LuLOFS et al. 1974). It is hoped that with the gazetting of the Tunku Abdul Rahman National Park so as to encompass Pulau Gaya and its surrounding reefs, the two damaged platform reefs will be allowed to regenerate. According to recent reports (D. JENKINS, pers. comm.) coral mining has decreased in the Kota Kinabalu area with construction companies now using mainly sand and quarried rock. 
NIGEL P.E. LANGHAM and JACK A. MATHIAS

\section{PROTECTED AREAS}

There are still a number of islands and their fringing reefs that should receive similar protection while their coral reefs are still in relatively good condition. This is particularly so for the islands of the Pulau Tega group and Pulau Balumbangan. In 1973, tourist income in Malaysia was M\$ 230 million (US\$ 90 million) or 4.5 percent of foreign exchange. Despite the world's present economic position, it is projected that by 1980, this will have reached about 7.6 percent of foreign exchange. In Sabah, in particular, tourism has increased with many tourists visiting the Mount Kinabalu National Park. It is hoped that the recently established marine park near Kota Kinabalu will encourage these tourists to spend a longer time in the area so as to justify the setting up of such a park and encourage the State to set aside further similar areas.

\section{ACKNOWLEDGEMENTS}

We are grateful to Dr. MARK VALENCIA, formerly of the School of Physics, Universiti Sains Malaysia and Mr. RICHARD LULOFS, for their assistance in making the present survey. We wish to thank Tan Sri Datuk Professor HAMZAH SENDUT, Vice-Chancellor, and Professor C.P. RAMACHANDRAN, Dean School of Biological Sciences, Universiti Sains Malaysia for their support and use of facilities, and the Fisheries Department of Sabah for supplying a research vessel for our survey. Finally we wish to thank Exxon Exploration (Malaysia) Inc., for funding this survey.

\section{REFERENCES}

CHUA, T.E. and J.A. MATHIAS 1975. Coastal resources of West Sabah. A preliminary investigation in relation to oil-spill. Universiti Sains Malaysia : 1 - 389

LULOFS, R.B. 1973. A reef survey of Pulau Gaya and associated islands, Sabah, June 8-12 1973. Unpublished report to the Sabah Parks Department.

LULOFS, R.B., N.P.E. LANGHAM, and J.A. MATHIAS 1974. A reef survey of Pulau Gaya and associated islands. Part II. Sabah, March 14-17 1974. Unpublished report to the Sabah Parks Department.

MATHIAS, J.A. and N,P.E. LANGHAM 1975. Coral reefs. In "Coastal resources of West Sabah" by Chua, T.E. and J.A. Mathias : 153 - 209.

WOOD. E.J.F. and R.E. JOHANNES. 1975. Tropical Marine Pollution. Elsivier Oceanography Series. V. 12. Elsivier Pub. Co. Amsterdam and New York : 1 - 192. 